\title{
Exploration of the Basolateral Chloride Channels in the Renal Tubule using the Patch-Clamp Technique
}

\author{
Jacques Teulon Stéphane Lourdel Antoine Nissant Marc Paulais \\ Romain Guinamard Pedro Marvao Martine Imbert-Teboul \\ UMR 7134 CNRS-UPMC, Centre de Recherches Biomédicales des Cordeliers, Paris, France
}

\author{
Key Words \\ CIC-K channel - Cystic fibrosis transmembrane \\ conductance regulator - Chloride - Renal tubule • \\ Basolateral membrane $\cdot$ Patch-clamp
}

\begin{abstract}
Chloride channels located on the basolateral membrane are known to be involved in chloride absorption in several parts of the renal tubule, and particularly in the thick ascending limb and distal convoluted tubule. The data available suggest that the $\mathrm{CIC}-\mathrm{K}$ channels play the major role in this process. We provide here a description of the electrophysiological properties of these channels, still very incomplete at this stage, and we attempt to compare $\mathrm{CIC}-\mathrm{Ks}$ to three chloride channels that we have identified in the basolateral membrane of microdissected fragments of the mouse renal tubule using the patchclamp technique. Based on anion selectivity and dependence on external $\mathrm{pH}$ and calcium shown by the CIC-Ks, we propose candidate $\mathrm{CIC}-\mathrm{K} 1$ and $\mathrm{CIC}-\mathrm{K} 2$ in native tissue. We also discuss the possibility that chloride channels that do not belong to the $\mathrm{CIC}$ family may also be involved in the absorption of chloride across the cortical thick ascending limb.
\end{abstract}

Copyright $\subset 2005$ S. Karger AG, Basel

This article is based on an invited lecture delivered at the 71st Congress of the French Society of Physiology in Paris, September 2004.
Current knowledge suggests that the $\mathrm{ClC}-\mathrm{K} 1$ and $\mathrm{ClC}$ $\mathrm{K} 2$ chloride channels (and their human orthologs $\mathrm{ClC}-\mathrm{Ka}$ and $\mathrm{ClC}-\mathrm{Kb}$ ) play a major role in the basolateral step of chloride absorption in the distal nephron, i.e. in the thick ascending limb (TAL) and distal convoluted tubule (DCT). A first piece of evidence is that mutations of the gene encoding $\mathrm{ClC}-\mathrm{Kb}$ are responsible for type-III Bartter syndrome (targeting TAL) and mixed Bartter-Gitelman syndrome (targeting TAL and DCT), whereas mutations of the regulatory Barttin subunit are responsible for typeIV Bartter syndrome [1-3]. Secondly, using antibodies that do not distinguish between the two isoforms, it has been shown that rat $\mathrm{ClC}-\mathrm{K}$ channels are located on the basolateral membrane of the distal nephron [4, 5], where they could be involved in $\mathrm{Cl}^{-}$absorption. In addition, $\mathrm{ClC}-\mathrm{K} 1 \mathrm{KO}$ mice have been used to confirm the presence of $\mathrm{ClC}-\mathrm{K} 2$ channels in the basolateral membranes of the TAL and DCT. ClC-K2 channels are also found in the intercalated cells of the collecting duct [6].

Several questions about the ClC-Ks remain to be answered. We still have not identified the corresponding channels in native tissue and we still do not know how they are regulated with regard to their supposed physiologic function or why two closely related entities ( $90 \%$ of sequence identity [7]) should occur in the same organ. Most of the data available about $\mathrm{Cl}^{-}$channels in the native renal tubule derive from experiments in the rabbit or mouse. In what follows, we review some of the properties of $\mathrm{ClC}$ and $\mathrm{ClC}-\mathrm{K}$ channels, compare cloned $\mathrm{ClC}-\mathrm{K}$ channels to en-

Jacques Teulon

CNRS-UPMC 7134, Centre de Recherches Biomédicales des Cordeliers

15 , rue de l'Ecole-de-Médecine

FR-75270 Paris CEDEX 06 (France)

Tel. +33155427864, Fax +331463341 72, E-Mail jacques.teulon@bhdc.jussieu.fr

$\begin{array}{ll}\text { KARGER } & \text { ( ) 2005 S. Karger AG, Basel } \\ \text { Fax +41 61 306 1234-2137/05/0992-0064\$22.00/0 } \\ \begin{array}{l}\text { E-Mail karger@karger.ch } \\ \text { www.karger.com }\end{array} & \begin{array}{l}\text { Accessible online at: } \\ \text { www.karger.com/nep }\end{array}\end{array}$


dogenous chloride channels (focusing on the mouse renal tubule) and present some data concerning regulation.

\section{Electrophysiological Properties of the CIC Chloride Channels}

The ClC-Ks belong to the first subfamily of the $\mathrm{ClC}$, voltage-dependent chloride channel family, the archetype of which is the chloride channel of the electric organ of the torpedo $\mathrm{ClC}-0$ [7]. All the channels of this subfamily, which also includes $\mathrm{ClC}-1$ and $\mathrm{ClC}-2$, are expressed at the plasma membrane, unlike other $\mathrm{ClCs}$, which occur essentially on the membranes of organelles. Electrophysiological studies from the laboratories of Miller and White [8] and Ludewig et al. [9] have shown that $\mathrm{ClC}-0$ is composed of two independent pores, known as protopores, and is endowed with double voltage dependence. A fast gate opens each protopore independently upon depolarization, whereas very slow, hyperpolarization-dependent activation commands a common gate. The double-pore structure is quite certainly a general characteristic of the $\mathrm{ClC}$ channels, since recent crystallography data have demonstrated such an arrangement for two bacterial $\mathrm{ClC}$ channels $[10,11]$. Likewise, voltage-dependence is a common property of the $\mathrm{ClCs}$, but appears to vary considerably from one channel to another: for instance, $\mathrm{ClC}-2$ is mainly gated by hyperpolarization [7]. Two additional properties of the ClCs are worth mentioning in this context [7]: dependence on the concentration of chloride ions and on $\mathrm{pH}$. It has been clearly demonstrated for both $\mathrm{ClC}$ 0 (fast gate) and $\mathrm{ClC}-1$ that depolarization-dependent activation is shifted towards more positive voltages when the external chloride concentration is lowered [12-14] or the internal $\mathrm{pH}$ increased $[14,15]$. In addition, lowering the intracellular chloride concentration has a complex effect on the kinetics of ClC- 0 : The open probability $\left(\mathrm{P}_{\mathrm{o}}\right)$ of the fast gate is reduced at negative voltage [13] and the slow (common) gate is inhibited [16]. It is noteworthy that elevating the intracellular chloride concentration stimulates the activity of native $\mathrm{ClC}$-2-like channels $[17,18]$. The $\mathrm{ClC}-0, \mathrm{ClC}-1$ and $\mathrm{ClC}-2$ channels all display greater activity when the external $\mathrm{pH}$ is lowered [7, 14, 15, 19].

Despite their having been cloned a decade ago [2022], little is known about the functional properties of the ClC-Ks because, except for rat ClC-K1, they are not expressed functionally in the oocyte in the absence of the regulatory Barttin subunit, which was not cloned until 2001 [4]. Recent co-expression studies have demonstrated two fundamental properties. On the one hand anion permeabilities follow the sequence $\mathrm{Cl}^{-}>\mathrm{Br}^{-}>\mathrm{NO}_{3}{ }^{-}>$
$\mathrm{I}^{-}$for $\mathrm{ClC}-\mathrm{K} 1$, and $\mathrm{Cl}^{-}>\mathrm{Br}^{-}=\mathrm{NO}_{3}{ }^{-}>\mathrm{I}^{-}$for $\mathrm{ClC}-\mathrm{K} 2[4$, 23 ], matching the permeability sequence of other members of the first $\mathrm{ClC}$ subfamily. On the other hand the currents are enhanced by a basic external $\mathrm{pH}$, which is the opposite of that observed for the other channels of the first subfamily, and by an elevated concentration of external calcium [4, 23]. In addition, it is likely that the $\mathrm{ClC}-\mathrm{Ks}$ are endowed with other common properties of the $\mathrm{ClCs}$, such as the double-pore architecture, sensitivity to chloride and voltage dependence. However, voltage dependence does not seem to be prominent over the range tested [4,23]. Finally, the unit conductance of these channels has not yet been determined.

\section{A CIC-K2 Candidate in the Native Mouse Renal Tubule}

The early DCT (DCT1) absorbs $\mathrm{NaCl}$ via a $\mathrm{Na}^{+}-\mathrm{Cl}^{-}$ cotransporter located at the apical membrane and $\mathrm{Na}^{+}, \mathrm{K}^{+}$ATPase on the basolateral side. $\mathrm{Cl}^{-}$transport across the basolateral membrane can be expected to proceed via conductive pathways, but there were no data on native DCT channels until our study. Using the patch-clamp on microdissected fragments of mouse DCT1, we detected a chloride channel of $\sim 9 \mathrm{pS}$ that exhibits several of the properties of $\mathrm{ClCs}$ and $\mathrm{ClC}-\mathrm{Ks}$ [24]. Firstly, the channel often produced a half conductance level that was reminiscent of a double-pore arrangement. However, this observation is not entirely conclusive, because transitions from halfopening to complete closure have rarely been observed. This contrasts with the behavior of $\mathrm{ClC}-0$, where the channel clearly fluctuates between a non-conducting level and two equally spaced conducting levels [8, 9]. Half-amplitude openings could, therefore, just as well correspond to a conventional sub-state of the channel. Secondly, and more conclusively, like the $\mathrm{ClC}-\mathrm{Ks}$, the channel has been shown to depend on external calcium levels and $\mathrm{pH}: \mathrm{NP}_{0}$ increased threefold when the calcium in the pipette (extracellular medium) was increased from zero to $5 \mathrm{~m} M$, and fifteen-fold when the $\mathrm{pH}$ was increased from 6.4 to 8.0. Thirdly, setting aside $\mathrm{I}^{-}$, the permeability sequence $\mathrm{Cl}^{-}$ $\sim \mathrm{I}^{-}>\mathrm{Br}^{-} \sim \mathrm{NO}_{3}^{-}>\mathrm{F}^{-}$observed for this channel matches that for ClC-K2. Finally, single-cell RT-PCR experiments have shown that only CLC-K2 mRNA was present in the DCT1, where the investigation was done [25]. Taking all these elements into account, it is reasonable to propose that this $\sim 9-\mathrm{pS}$ chloride channel corresponds to $\mathrm{ClC}-\mathrm{K} 2$. Sauve et al. [26] have reported a fairly similar $\mathrm{Cl}^{-}$channel (conductance $14 \mathrm{pS}$ ) in membrane vesicles from the rabbit distal nephron incorporated into lipid bi-layers. As in our 
study, the channel showed greater activity in the presence of higher extracellular $\mathrm{pH}$ or calcium levels.

We have investigated several regulatory properties which have not yet been investigated in cloned ClC-Ks. Channel activity is gradually inhibited in the presence of PMA, an activator of PKC, but does not seem to be modulated via the adenylyl cyclase pathway: neither forskolin in cell-attached patches nor the catalytic subunit of PKA in excised patches alter channel activity [24]. The channel is insensitive to intracellular calcium levels but, in contrast, is highly sensitive to the intracellular $\mathrm{pH}$. Taking the activity at $\mathrm{pH} 7.4$ as baseline, $\mathrm{pH} 6.8$ decreases channel activity by $70 \%$, whereas $\mathrm{pH} 8.0$ increases it by $350 \%$. $\mathrm{pH}$ could therefore be a major regulator of the $\mathrm{ClC}-\mathrm{K} 2$ channel, since the activity of the channel is also lower at an acid extracellular $\mathrm{pH}$.

We have detected a channel with the same unit conductance and anion selectivity in the connecting tubule (unpublished results), and also in the mouse DCT2 [25] and cortical thick ascending loop (CTAL; unpublished results), both of which are segments in which a second 9- $\mathrm{pS} \mathrm{Cl}^{-}$ channel with very different anion selectivity is also present [27] (see 'A Pseudo-CFTR Chloride Channel' below).

\section{A Possible CIC-K1 Candidate}

We detected a chloride channel with a unit conductance of $45 \mathrm{pS}$ in the mouse CTAL [28], and which has a permeability sequence $\left(\mathrm{Cl}^{-}>\mathrm{Br}^{-}>\mathrm{NO}_{3}{ }^{-}\right)$compatible with that of ClC-K1. We did not investigate its dependence upon external $\mathrm{pH}$ or calcium level, which had not yet been identified as a characteristic feature of the ClC-Ks at the time of our experiments. Further information is needed before we can decide whether this corresponds to $\mathrm{ClC}-\mathrm{K} 1$. The channel is activated by depolarization (like $\mathrm{ClC}-1$ and the fast gate of $\mathrm{ClC}-0$ ), but is insensitive to intracellular calcium levels and $\mathrm{pH}$. Intriguingly, this channel seems to be indirectly stimulated via the adenylyl cyclase pathway: the chance of recording the channel increased eightfold (from 8 to $67 \%$ ) when the tubules were pre-incubated with forskolin for about $15 \mathrm{~min}$. However, application of the catalytic subunit of the PKA had no effect on inside-out patches, suggesting that direct phosphorylation is not responsible for its activation [27].

Chloride channels with similar conductance have been recorded in the rabbit kidney, but their anion selectivity was not investigated. Using the patch-clamp technique, Sansom et al. [29] reported a 49-pS Cl${ }^{-}$channel in the basolateral membrane of the principal cells of the rabbit cortical collecting duct with two open current levels. Win- ters et al. [30] recorded $\mathrm{Cl}^{-}$channels on vesicles from the rabbit renal outer medulla (MTAL channel) and basolaterally enriched vesicles from cultured mouse CTAL cells (CTAL channel) [31], incorporated into planar lipid bilayers. Both channels had a conductance of $80-90 \mathrm{pS}$ in symmetrical $300 \mathrm{mM} \mathrm{KCl}[31,32]$ (about $50 \mathrm{pS}$ in $150 \mathrm{mM} \mathrm{KCl}$ [30]), and were activated by membrane depolarization, like $\mathrm{ClC}-0$ and $\mathrm{ClC}-1$. The activity of the MTAL channel, but not of the CTAL channel, decreased when the intracellular chloride concentration was lowered, as for $\mathrm{ClC}-0$ or for $\mathrm{ClC}-2$-like channels, and increased in the presence of PKA (at low intracellular concentrations of chloride). The former regulatory process is particularly relevant in the context of $\mathrm{Cl}^{-}$-transporting epithelia, because chloride could be the cross-talk agent that coordinates the activities of anion transporters on one membrane and of anion channels on the other.

\section{A Pseudo-CFTR Chloride Channel}

As already mentioned, there is a 9-pS chloride channel in the basolateral membrane of the mouse CTAL that has a permeability sequence $\mathrm{I}^{-}>\mathrm{NO}_{3}^{-}>\mathrm{Br}^{-}>\mathrm{Cl}^{-}[27,33]$. This anion selectivity contrasts sharply with the permeability sequence of the ClC-Ks, and more generally with that of the other members of the first $\mathrm{ClC}$ subfamily. A channel with similar conductance and selectivity has also been found in the mouse DCT2 [25]. The channel is activated by intracellular ATP, pyrophosphate (in the presence of ATP; fig. 1) and the catalytic subunit of PKA. It is insensitive to intracellular calcium, but highly sensitive to intracellular $\mathrm{pH}$ [33]. At the time of these experiments, we were puzzled by similarities between this channel and the cystic fibrosis transmembrane conductance regulator (CFTR), which included activation by ATP, pyrophosphate and PKA, and also anion selectivity and pharmacological profile. We investigated this question using CFTR $\mathrm{KO}$ mice, and were able to demonstrate that these two channels are distinct entities, despite their functional similarities [34]. Thus, the molecular identity of this 'pseudoCFTR' channel remains to be determined. Segal et al. [35] have described a $\mathrm{Cl}^{-}$channel that closely resembles our pseudo-CFTR channel in terms of the conductance and regulation in the basolateral membrane of the rabbit proximal tubule. The pseudo-CFTR channel, being located at the basolateral membrane, is theoretically in the right position to contribute to the process of chloride absorption. However, this is difficult to ascertain directly in the absence of specific blockers, which would allow discrimination between this channel and the two other chloride channels also present in the CTAL basolateral membrane. 
Fig. 1. Representative recording of pseudoCFTR chloride channels on the basolateral membrane of mouse CTAL. These channels have a unit conductance of $9 \mathrm{pS}$, and are activated by intracellular ATP and pyrophosphate (PPi, in the presence of ATP). When ATP was removed from the solution, channel activity decreased progressively over time. In contrast, the ClC-K2 candidate (which has a similar conductance) was not sensitive to these factors. Channel activity is shown on the right-hand side of the traces as the product of channel number and open probability.

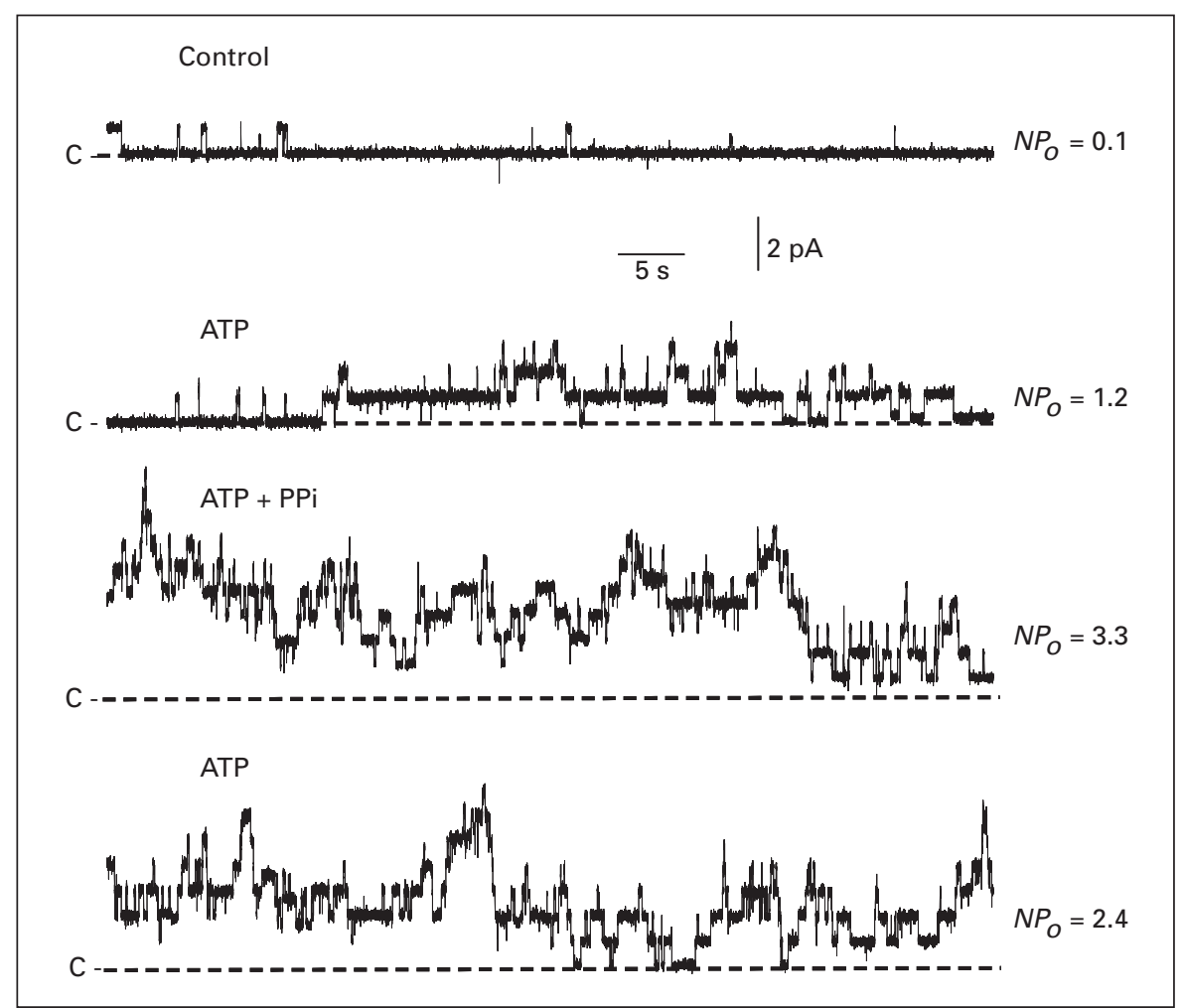

Table 1. A summary of the data on basolateral $\mathrm{Cl}^{-}$channels derived from experiments on microdissected mouse renal tubules

\begin{tabular}{rlllll}
\hline $\mathrm{g}(\mathrm{pS})$ & $\begin{array}{l}\text { Proposed } \\
\text { identity }\end{array}$ & Selectivity & $\begin{array}{l}{\left[\mathrm{Ca}^{2+}\right]_{\mathrm{e}} /} \\
\text { basic } \mathrm{pH}_{\mathrm{e}}\end{array}$ & $\begin{array}{l}\text { Basic } \\
\mathrm{pH}\end{array}$ & Tubule \\
\hline 45 & $\mathrm{ClC}-\mathrm{K} 1$ & $\mathrm{Cl}^{-}>\mathrm{Br}^{-}>\mathrm{NO}_{3}^{-}$ & $?$ & - & CTAL [28] \\
9 & $\mathrm{ClC}-\mathrm{K} 2$ & $\mathrm{Cl}^{-}>\mathrm{I}^{-}>\mathrm{Br}^{-}=\mathrm{NO}_{3}^{-}$ & + & + & DCT1 [24], \\
& & & & & DCT2 [25] \\
9 & Non-ClC & $\mathrm{I}^{-}>\mathrm{NO}_{3}{ }^{-}>\mathrm{Br}^{-}>\mathrm{Cl}^{-}$ & $?$ & + & $\begin{array}{l}\text { CTAL [27, 33], } \\
\end{array}$ \\
& & & & DCT2 [25]
\end{tabular}

Activation by the designated agents is indicated by + , and a lack of effect by -. Not every regulating process has been demonstrated to occur in each part of the tubule. The proposed molecular identity is speculative at this stage.

\section{Conclusions}

Table 1 summarizes the properties of the three basolateral $\mathrm{Cl}^{-}$channels that we have described in the mouse renal tubule. It also includes speculation about their molecular identity. We should point out that the two ClC-K candidates have several contrasting properties, including their conductance ( 9 vs. $45 \mathrm{pS}$ ), sensitivity to intracellular $\mathrm{pH}$ and dependence on cyclic AMP. This is rather surprising, since there is $90 \%$ sequence homology between the two ClC-Ks. It should also be emphasized that cyclic AMP has diverse effects on the three channels: the adenylyl-cyclase pathway has no effect on the ClC-K2 candidate, it appears to increase the number of active candidate $\mathrm{ClC}-\mathrm{K} 1$ channels, and stimulates the activity of the pseudo-CFTR channel via PKA. Lastly, functional diversity parallels heterogeneous distribution: we recorded all three types of channel in the CTAL, both the ClC-K2 candidate and non-ClC type in the late DCT, and the candidate ClC-K2 alone in the early DCT. This suggests that each $\mathrm{Cl}^{-}$channel may make a distinct contribution to the ion-transport process, and highlights the fact that further investigation is needed to elucidate their respective physiological functions.

The CFTR-like channel is most probably not a $\mathrm{ClC}$ channel, and its molecular identity has yet to be determined. Additional non-ClC channels could also be involved in $\mathrm{Cl}^{-}$absorption. Cyclic AMP-dependent, calcium-dependent and volume-dependent $\mathrm{Cl}^{-}$currents, have been reported in cultured renal cells using the whole-cell recording technique [36-46]. Cyclic AMP-dependent $\mathrm{Cl}^{-}$ currents are attributed to apical CFTR, but the possible presence of volume-dependent and calcium-dependent $\mathrm{Cl}^{-}$channels at the basolateral membrane remains to be investigated, especially in the native renal tubule. 


\section{References}

-1 Jeck N, Konrad M, Peters M, et al: Mutations in the chloride channel gene, CLCNKB, leading to a mixed Bartter-Gitelman phenotype. Pediatr Res 2000;48:754-758.

- 2 Simon DB, Bindra RS, Mansfield TA, et al: Mutations in the chloride channel gene, CLCNKB, cause Bartter's syndrome type III. Nat Genet 1997;17:171-178.

-3 Birkenhager R, Otto E, Schurmann MJ, et al: Mutation of BSND causes Bartter syndrome with sensorineural deafness and kidney failure. Nat Genet 2001;29:310-314.

-4 Estévez R, Boettger T, Stein V, et al: Barttin is a Cl${ }^{-}$channel beta-subunit crucial for renal $\mathrm{Cl}^{-}$ reabsorption and inner ear $\mathrm{K}^{+}$secretion. Nature 2001;414:558-561.

5 Vandewalle A, Cluzeaud F, Bens M, et al: Localization and induction by dehydratation of ClC-K chloride channels in the rat kidney. Am J Physiol 1997; 272:F678-F688.

-6 Kobayashi K, Uchida S, Mizutani S, et al: Intrarenal and cellular localization of CLC-K2 protein in the mouse kidney. J Am Soc Nephrol 2001;12:1327-1334.

-7 Jentsch TJ, Stein V, Weinreich F, Zdebik AA: Molecular structure and physiological function of chloride channels. Physiol Rev 2002;82: 503-568.

8 Miller C, White MM: Dimeric structure of single chloride channels from Torpedo electroplax. Proc Natl Acad Sci USA 1984;81:27722775.

-9 Ludewig U, Pusch M, Jentsch TJ: Independent gating of single pores in CLC-0 chloride channels. Biophys J 1997;73:789-797.

10 Dutzler R, Campbell EB, MacKinnon R: Gating the selectivity filter in $\mathrm{ClC}$ chloride channels. Science 2003;300:108-112.

11 Dutzler R, Campbell EB, Cadene M, et al: Xray structure of a $\mathrm{ClC}$ chloride channel at 3.0 A reveals the molecular basis of anion selectivity. Nature 2002;415:287-294.

12 Pusch M, Ludewig U, Rehfeldt A, Jentsch TJ: Gating of the voltage-dependent chloride channel CIC-0 by the permeant anion. Nature 1995; 373:527-531.

13 Chen TY, Miller C: Nonequilibrium gating and voltage dependence of the $\mathrm{ClC}-0 \mathrm{Cl}^{-}$channel. J Gen Physiol 1996;108:237-250.

-14 Rychkov GY, Pusch M, Astill DS, et al: Concentration and $\mathrm{pH}$ dependence of skeletal muscle chloride channel ClC-1. J Physiol 1996;497: 423-435.

15 Chen MF, Chen TY: Different fast-gate regulation by external $\mathrm{Cl}(-)$ and $\mathrm{H}(+)$ of the muscletype $\mathrm{ClC}$ chloride channels. J Gen Physiol 2001;118:23-32.

-16 Pusch M, Jordt SE, Stein V, Jentsch TJ: Chloride dependence of hyperpolarization-activated chloride channel gates. J Physiol 1999;515: 341-353.

17 Fritsch J, Edelman A: Modulation of the hyperpolarization-activated $\mathrm{Cl}^{-}$current in human intestinal T84 epithelial cells by phosphorylation. J Physiol 1996;490:115-128.
18 Chesnoy-Marchais D: Characterization of a chloride conductance activated by hyperpolarization in Aplysia neurones. J Physiol 1983; 342:277-308.

19 Maduke M, Miller C, Mindell JA: A decade of CLC chloride channels: Structure, mechanism, and many unsettled questions. Annu Rev Biophys Biomol Struct 2000;29:411-438.

20 Kieferle S, Fong P, Bens M, et al: Two highly homologous members of the $\mathrm{ClC}$ chloride channel family in both rat and human kidney. Proc Natl Acad Sci USA 1994;91:6943-6947.

21 Uchida S, Sasaki S, Furukawa T, et al: Molecular cloning of a chloride channel that is regulated by dehydratation and expressed predominantly in kidney medulla. J Biol Chem 1993;268:3821-3824.

22 Adachi S, Uchida S, Ito H, et al: Two isoforms of a chloride channel predominantly expressed in thick ascending limb of Henle's loop and collecting ducts of rat kidney. J Biol Chem 1994;269:17677-17683.

23 Waldegger S, Jeck N, Barth P, et al: Barttin increases surface expression and changes current properties of $\mathrm{ClC}-\mathrm{K}$ channels. Pflugers Arch 2002;444:411-418.

24 Lourdel S, Paulais M, Marvao P, et al: A chloride channel at the basolateral membrane of the distal-convoluted tubule: A candidate $\mathrm{ClC}$ K channel. J Gen Physiol 2003;121:287-300.

25 Nissant A, Lourdel S, Baillet S, et al: Heterogeneous distribution of chloride channels along the distal convoluted tubule probed by singlecell RT-PCR and patch-clamp. Am J Physiol Renal Physiol 2004;287:F1233-F1243.

26 Sauve R, Cai S, Garneau L, et al: pH and external $\mathrm{Ca}(2+)$ regulation of a small conductance $\mathrm{Cl}(-)$ channel in kidney distal tubule. Biochim Biophys Acta 2000;1509:73-85.

27 Guinamard R, Chraibi A, Teulon J: A smallconductance $\mathrm{Cl}^{-}$channel in the mouse thick ascending limb that is activated by ATP and protein kinase A. J Physiol (Lond), 1995;485: 97-112.

28 Paulais M, Teulon J: cAMP-activated chloride channel in the basolateral membrane of the thick ascending limb of the mouse kidney. $\mathrm{J}$ Membr Biol 1990;113:253-260.

29 Sansom SC, La BQ, Carosi SL: Double-barreled chloride channels of collecting duct basolateral membrane. Am J Physiol 1990;259: F46-F52.

30 Winters CJ, Reeves WB, Andreoli TE: $\mathrm{Cl}^{-}$ channels in basolateral TAL membranes. XIV. Kinetic properties of a basolateral MTAL $\mathrm{Cl}^{-}$ channel. Kidney Int 1999;55:1444-1449.

- 31 Winters CJ, Reeves WB, Andreoli TE: $\mathrm{Cl}^{-}$ channels in basolateral TAL membranes. XIII. Heterogeneity between basolateral MTAL and CTAL Cl- channels. Kidney Int 1999;55:593601.

32 Reeves WB, Andreoli TE: $\mathrm{Cl}^{-}$transport in basolateral renal medullary vesicles. II. $\mathrm{Cl}^{-}$channels in planar lipid bilayers. J Membr Biol 1990;113:57-65.
33 Guinamard R, Paulais M, Teulon J: Inhibition of a small-conductance cAMP-dependent $\mathrm{Cl}^{-}$ channel in the mouse thick ascending limb at low internal pH. J Physiol (Lond) 1996;490: 759-765.

34 Marvao P, De Jesus Ferreira MC, Bailly C, et al: $\mathrm{Cl}^{-}$absorption across the thick ascending limb is not altered in cystic fibrosis mice. A role for a pseudo CFTR $\mathrm{Cl}^{-}$channel. J Clin Invest 1998;102:1986-1993.

35 Segal AS, Geibel J, Boulpaep EL: A chloride channel resembling CFTR on the basolateral membrane of rabbit proximal tubule. J Am Soc Nephrol 1993;4:879a.

36 Vandorpe D, Kizer N, Ciampollilo F, et al: CFTR mediates electrogenic chloride secretion in mouse inner medullary collecting duct (mIMCD-K2) cells. Am J Physiol 1995;269: C683-C689.

37 Bens M, Van Huyen JP, Cluzeaud F, et al: CFTR disruption impairs cAMP-dependent $\mathrm{Cl}(-)$ secretion in primary cultures of mouse cortical collecting ducts. Am J Physiol Renal Physiol 2001;281:F434-F442.

38 Husted RF, Volk KA, Sigmund RD, Stokes JB: Anion secretion by the inner medullary collecting duct. Evidence for involvement of the cystic fibrosis transmembrane conductance regulator. J Clin Invest 1995;95:644-650.

39 Cuffe JE, Bielfeld-Ackermann A, Thomas J, et al: ATP stimulates $\mathrm{Cl}^{-}$secretion and reduces amiloride-sensitive $\mathrm{Na}^{+}$absorption in $\mathrm{M}-1$ mouse cortical collecting duct cells. J Physiol 2000;524:77-90.

40 Bertog M, Letz B, Kong W, et al: Basolateral proteinase-activated receptor (PAR-2) induces chloride secretion in M-1 mouse renal cortical collecting duct cells. J Physiol 1999;521:3-17.

41 Meyer K, Korbmacher C: Cell swelling activates ATP-dependent voltage-gated chloride channels in M-1 mouse cortical collecting duct cells. J Gen Physiol 1996;108:177-193.

42 Boese SH, Glanville M, Gray MA, Simmons NL: The swelling-activated anion conductance in the mouse renal inner medullary collecting duct cell line mIMCD-K2. J Membr Biol 2000; 177:51-64.

43 Boese SH, Glanville M, Aziz O, et al: $\mathrm{Ca}^{2+}$ and cAMP-activated $\mathrm{Cl}^{-}$conductances mediate $\mathrm{Cl}^{-}$ secretion in a mouse renal inner medullary collecting duct cell line. J Physiol 2000;523: 325-338.

44 Qu Z, Wei RW, Hartzell HC: Characterization of $\mathrm{Ca}^{2+}$-activated $\mathrm{Cl}^{-}$currents in mouse kidney inner medullary collecting duct cells. Am J Physiol Renal Physiol 2003;285:F326-F335.

45 Barriere H, Belfodil R, Rubera I, et al: CFTR null mutation altered cAMP-sensitive and swelling-activated $\mathrm{Cl}^{-}$currents in primary cultures of mouse nephron. Am J Physiol Renal Physiol 2003;284:F796-F811.

46 Rubera I, Tauc M, Michel F, et al: Simultaneous functional expression of swelling and forskolin-activated chloride currents in primary cultures of rabbit distal convoluted tubule. CR Acad Sci III 1997;320:223-232.
Teulon/Lourdel/Nissant/Paulais/ Guinamard/Marvao/Imbert-Teboul 